\title{
Bermain: Perspektif Tentang Pengalaman Bermain Guru PAUD dan Praktik Bermain Pada Pembelajaran di PAUD
}

\section{Dwi Hardiyanti}

Prodi Pendidikan Guru Pendidikan Anak Usia Dini, Fakultas Keguruan dan Ilmu Pendidikan, Universitas IVET, Indonesia

\section{Info Articles}

Sejarah Artikel:

Disubmit 4 Juli 2021

Direvisi 6 Juli 2021

Disetujui 31 Juli 2021

\section{Keywords:}

Early childhood; Teacher; Perpectivess toward playing; Previous experience of play

\begin{abstract}
Abstrak
Studi deskriptif ini dibingkai dalam iklim akademik saat ini di mana bermain telah berkurang di ruang kelas anak usia dini (Falk, 2012; Hirsh-Pasek, Golinkoff, Berk \& Singer, 2009; Miller \& Almon, 2009). Bermain di pembelajaran juga harus dipahami bukan sebagai ancaman, tetapi alat untuk konten akademik dan persiapan untuk pembelajaran di masa depan. Pernyataan tersebut jika benar diterapkan maka guru, sekolah dan orangtua tidak akan merasa benar saat proses bermain itu sendiri didorong keluar dari kurikulum prasekolah karena berbagai alasan, termasuk kebutuhan untuk mempersiapkan anak-anak untuk penilaian standar (Chervenak, 2011; Drew, Christie, Johnson, Meckley \& Nell, 2008). Hal lain yang perlu diingat adalah, jika guru merupakan bagian kunci dalam apa yang dianggap sebagai pengalaman bermain berkualitas untuk anak-anak (Hadley, 2002; Hirsh-Pasek, Golinkoff, Berk \& Singer, 2009; Jones \& Reynolds, 2011; Kontos, 1999; Korat, Bahar \& Snapir, 2003), maka persepsi dan pengalaman guru dengan bermain menjadi bagian penting dari apa yang dianggap sebagai "pedagogi bermain"(Ryan \& Northey-Berg, 2013, hal. 4). Pengalaman dan perspektif guru terhadap bermain yang akan memainkan peranan penting dalam menentukan keberhasilan proses pembelajaran pada AUD.
\end{abstract}

\section{Abstract}

This descriptive study is framed in the current academic climate where play has diminished in early childhood classrooms (Falk, 2012; Hirsh-Pasek, Golinkoff, Berk \& Singer, 2009; Miller \& Almon, 2009). Play in learning should also be understood not as a threat, but a tool for academic content and preparation for future learning. If this statement is properly applied then teachers, schools and parents will not feel right when the play process itself is pushed out of the preschool curriculum for a variety of reasons, including the need to prepare children for standardized assessment (Chervenak, 2011; Drew, Christie, Johnson, Meckley \& Nell, 2008). Another thing to keep in mind is that teachers are a key part of what is considered a quality play experience for children (Hadley, 2002; Hirsh-Pasek, Golinkoff, Berk \& Singer, 2009; Jones \& Reynolds, 2011; Kontos, 1999). ; Korat, Bahar \& Snapir, 2003), then teachers' perceptions and experiences with play become an important part of what is considered a "play pedagogy" (Ryan \& Northey-Berg, 2013, p. 4). The teacher's experience and perspective on play will play an important role in determining the success of the AUD learning process.
Alamat Korespondensi:
E-mail: alamat@email.mu
p-ISSN XXXX-XXX e-ISSN XXXX-XXX 


\section{PENDAHULUAN}

Bermain adalah aktivitas yang signifikan dalam kehidupan seorang anak. Melalui bermain, anak-anak bertemu dan menjelajahi dunia mereka dan membangun pemahaman dan identitas mereka di dalamnya. Peneliti dan pendidik menekankan pentingnya bermain dan sentralitasnya untuk pembelajaran anak-anak (Singer, 2015). Memberikan anak-anak kesempatan untuk berlatih bermain bebas diharapkan dapat meningkatkan pembelajaran, motivasi, dan pengaturan diri mereka (Wasik \& Jacobi-Vessels, 2017; National Association for the Education of Young Children, 2009). Selain itu, pembelajaran berbasis bermain dapat digunakan secara efektif untuk meningkatkan tes prestasi skor, tingkat kelulusan dari sekolah menengah, dan penurunan tingkat kejahatan dan kenakalan (Barnett \& Camili, 2002; Cutter-Mackenzie \& Edwards, 2013; Sandberg \& rlemalm-Hagsér, 2011). Anak-anak tidak memisahkan belajar dari bermain (Samuelsson \& Carlsson, 2008), sehingga guru pada tingkat pendidikan anak usia dini diharapkan memberikan siswa mereka kesempatan belajar yang efektif untuk menghubungkan konten instruksional dengan pedagogi bermain. Beberapa strategi telah dikembangkan untuk digunakan guru dalam pelaksanaan pembelajaran berbasis bermain; yang paling umum termasuk pusat pembelajaran, permainan, eksplorasi langsung, dan pusat bermain atau pilihan bebas pusat (Chervenak, 2011).

Terlepas dari pentingnya bermain dalam perkembangan anak-anak, bermain sendiri telah didorong keluar dari kurikulum prasekolah karena berbagai alasan, termasuk kebutuhan untuk mempersiapkan anak-anak untuk penilaian standar (Chervenak, 2011; Drew, Christie, Johnson, Meckley \& Nell, 2008). Dalam masyarakat saat ini, kita melihat tidak hanya fenomena guru yang tidak dapat berpartisipasi dalam permainan anak-anak karena berbagai kendala, tetapi juga bahwa permainan anak-anak dilihat sebagai hal yang membuang-buang waktu. Jika kegiatan tersebut tidak produktif, maka tidak ada nilainya dalam masyarakat di mana hubungan antara pekerjaan dan valuasi waktu \& uang begitu terkait erat (Faulkner, 2011). Misi sekolah telah didefinisikan ulang oleh definisi produktivitas secara keseluruhan dalam masyarakat modern. Sekolah juga berusaha untuk mengikuti budaya yang cepat dan fokus ke depan; guru berkewajiban untuk menyampaikan konten akademis yang berat, bahkan di kelas-kelas pendidikan awal. Bermain dihapus seluruhnya atau dibingkai kembali dalam bentuk permainan edukatif dengan berlandaskan pendekatan yang lebih awal lebih baik (Katz, 2015) yang menghargai prestasi akademik secara keseluruhan sebagai produk proses belajar mengajar.

Sementara upaya advokasi hak anak untuk bermain telah meningkat secara signifikan selama dekade terakhir terutama di dunia pendidikan barat, upaya ini belum tentu diterjemahkan ke dalam praktik pengajaran dalam iklim akademik saat ini (Falk, 2012; Hirsh-Pasek, Golinkoff, Berk \& Singer, 2009; Miller \& Almon, 2009). Jika guru adalah bagian kunci dalam apa yang dianggap sebagai pengalaman bermain berkualitas untuk anak-anak (Hadley, 2002; Hirsh-Pasek, Golinkoff, Berk \& Singer, 2009; Jones \& Reynolds, 2011; Kontos, 1999; Korat, Bahar \& Snapir, 2003), maka persepsi dan pengalaman guru dengan bermain menjadi bagian penting dari apa yang dianggap sebagai "pedagogi bermain"(Ryan \& Northey-Berg, 2013, hal. 4). Pengalaman khusus setiap guru di masa kecil dalam bermain dan perkembangan karir masing-masing guru pasti unik dan berbeda satu sama lain, tetapi keterkaitan sejarah bermain pribadi dan pilihan dalam praktik pedagogis individu tidak berbeda dimana bagi seorang pendidik, bermain seringkali bergeser ke diskusi tentang pengalaman masa kecil mereka bermain.

Pengalaman bermain saat masih anak-anak akan membantu membentuk bagaimana guru tersebut memandang bermain sebagai sebuah metode pembelajaran. Pentingnya perkembangan bermain adalah prinsip utama pendidikan anak usia dini, namun banyak guru memperjuangkan bermain sebagai fokus utama di kelas mereka sendiri. Hal ini terutama disebabkan karena mulai bergesernya kurikulum pada pendidikan anak usia dini yang lebih ke arah standarisasi penilaian 
untuk level pendidikan selanjutnya. Hatcher dkk.,(2012) mencatat bahwa karena transformasi dalam kurikulum ini terkait dengan kesiapan taman kanak-kanak, persyaratan keterampilan untuk anakanak prasekolah menjadi lebih kompleks daripada yang seharusnya disesuaikan untuk usia kronologis dan tahap perkembangan anak usia dini. Nicolopoulou dkk. (2010) melakukan studi kasus dua tahun yang mendukung keseimbangan pengajaran langsung dan permainan yang berpusat pada anak untuk menyediakan lingkungan yang kaya akan literasi sosial, kognitif, dan awal. Para peneliti menemukan bahwa tren saat ini dalam pengajaran adalah instruksi langsung atau instruksi eksplisit yang berfokus pada seperangkat keterampilan, dan sangat sedikit penekanan yang ditempatkan pada signifikansi dan nilai bermain untuk anak-anak prasekolah (Nicolopoulou dkk.,2010). Mereka berpendapat bahwa anak-anak belajar paling baik ketika diberikan pilihan, dan ketika pembelajaran itu relevan dan dalam konteks (Nicolopoulou dkk.,2010).

Penelitian terus menunjukkan peran penting dari bermain di pembelajaran dan perkembangan anak-anak, dan tempat bermain bukan sebagai ancaman, tetapi alat untuk konten akademik dan persiapan untuk pembelajaran di masa depan. (Elkind, 2008; Hirsh-Pasek, Golinkoff, Berk \& Singer, 2009; Gopnik 2009; Miller \& Almon, 2009). Lebih khusus lagi, permainan role play atau bermain peran telah terbukti menjadi alat penting untuk pertumbuhan sosial emosional dan akademik anak-anak. Selain manfaat akademis dan sosial emosional ini dari bermain peran atau role play, banyak penelitian lain yang sangat menyarankan bahwa permainan peran memiliki dampak positif pada kesiapan sekolah (Bowman, Donovan, \& Burns, 2000; Shonkoff \& Phillips, 2000). Penelitian tersebut telah membantu melegitimasi peran penting permainan peran di kelas, sedemikian rupa sehingga bukti menunjukkan bahwa lingkungan belajar awal tanpa kurikulum yang menyenangkan dapat berbahaya bagi perkembangan akademik dan sosial emosional anak-anak (Falk, 2012; Miller \& Almon, 2009; National Association for the Education of Young Children, 2003; National Association of School Psychologists, 2005).

Berdasarkan narasi diatas, bermain secara teori sangat didukung untuk menjadi kurikulum utama dalam proses pembelajaran pada tingkat pendidikan awal/taman kanak-kanak/PAUD. Namun pada kenyataannya, banyak hal yang membuat bermain sambil belajar dipandang sebagai cara belajar yang kurang efektif. Penilaian terhadap sistem pembelajaran dengan bermain yang kurang efektif ini timbul karena adanya pergeseran kurikulum dimana anak-anak usia dini dituntut dengan tuntutan akademis untuk menyiapkan mereka pada tahap pendidikan selanjutnya. Selain pergeseran kurikulum, perspektif guru terhadap bermain juga ikut memainkan peran di mana guru yang perspektifnya positif untuk bermain, lebih mungkin mendorong proses belajar sambil bermain. Namun, jenis permainan pun juga ikut berperan di mana bermain secara bebas memberikan hasil pembelajaran positif dibandingkan dengan permainan terpola yang diinisiasi oleh Guru. Tujuan dari artikel ini adalah untuk lebih memahami bagaimana bermain terjadi di awal pendidikan anak, apa konsepsi anak dan guru? Dan bagaimana konsepsi ini berinteraksi dengan satu sama lain dalam melakukan permainan di sekolah.

\section{PERSPEKTIF GURU DAN BERMAIN}

Indikasi bahwa anak-anak belajar melalui bermain telah diteliti dan dicatat bermanfaat dalam mengembangkan bahasa, keterampilan sosial, emosional, dan prestasi akademik anak-anak usia dini yang mendukung kesiapan sekolah (Bodrova, Germeroth, \& Leong, 2013; Myck-Wayne, 2010; Pyle \& Bigelow, 2015). Namun, ketika melihat ke belakang selama setengah abad terakhir di Amerika Serikat dan negara-negara lain, ada tekanan akademis yang ditempatkan pada pendidik awal serta orang tua untuk menyebabkan penurunan permainan dan reformasi dalam menjadikan prestasi akademik sebagai prioritas (Gray, 2011; 2014). Brown dan Lan (2015), DellaMatera (2010) dan Kohn (1999) menyatakan bahwa semakin awal sekolah mencoba memasukkan keterampilan 
akademik, semakin besar kesenjangan pencapaian, karena instruksi langsung yang guru membaca dari skrip yang disiapkan dan menggunakan latihan dan praktik yang berfokus pada pengajaran keterampilan khusus tidak sesuai untuk perkembangan anak usia dini. Dengan perubahan kurikulum dan harapan di Taman kanak-kanak bagi anak-anak untuk membaca dan menulis ada tekanan bagi guru untuk memberikan waktu lebih sedikit untuk bermain dan lebih banyak pengajaran langsung (Gilbert, Harte \& Patrick, 2011).

Dengan kondisi tuntutan akademis yang seharusnya tidak mendominasi di tingkat awal pendidikan anak usia dini, bermain dapat menjadi sesuatu yang membebaskan bagi anak. Menurut anak-anak, mereka bermain hanya karena mereka suka bermain: "Karena kami suka bermain". Persepsi anak-anak ini memperkuat apa yang ditunjukkan oleh beberapa ahli, di antaranya Piaget (1962) dan Vygotsky (1978), mengenai salah satu yang paling penting dalam karakteristik bermain adalah bermain itu mengandaikan atau secara spontan terjadi penyisipan sukarela (ketika undangan dari satu anak ke anak lain untuk bermain diterima). Ketika ditanya tentang kapan mereka bermain, anak-anak awalnya seringkali tidak menyebutkan momen-momen yang dialami di sekolah. Mereka mengatakan bahwa mereka bermain "pada malam dan sore hari", "dalam pagi, ketika tidak ada sekolah, "yaitu, periode ketika mereka tidak di sekolah adalah yang pertama ditunjukkan sebagai waktu bermain. Baru kemudian mereka menyebutkan saat-saat ketika mereka bermain di sekolah, yaitu "waktu istirahat" dan "waktu jajan". Hal ini menunjukkan bahwa bahkan sejak level pendidikan awal, sekolah tidak pernah dianggap sebagai sarana untuk anak bermain sehingga integrasi sistem pembelajaran sambil bermain tidak dapat sepenuhnya diterapkan.

Konsep bermain sambil belajar yang banyak digaungkan dalam metode pendidikan anak usia dini seringkali tidak menitikberatkan pada bermain tetapi lebih kepada isi atau tujuan dari permainan tersebut yang cenderung pada peningkatan kemampuan akademik. Namun, dengan kondisi tersebut, sekolah tetap merasa bahwa teknik yang mereka gunakan menyenangkan bagi anak karena menggunakan permainan. Argumen untuk apresiasi bermain oleh sekolah adalah fakta bahwa itu adalah alat belajar: sementara bermain bebas adalah "berantakan", bermain terbimbing mempromosikan pembelajaran. Itu adalah konsepsi antagonis tentang gerakan/kebisingan /permainan dan pembelajaran/pengembangan/pendidikan. Kejadian-kejadian di mana aktivitas yang diusulkan oleh guru dipahami sebagai permainan oleh anak-anak jarang terjadi. Di sisi lain, permainan apa pun yang diprakarsai sendiri oleh anak cenderung tidak dihargai oleh guru.

Devaluasi permainan bebas oleh guru juga dibuktikan oleh peneliti lain, antara lain oleh Cruz dan Santos (2016). Ada perbedaan yang signifikan dalam perspektif anak-anak dan guru mengenai makna yang dikaitkan dengan bermain di lingkungan sekolah: anak-anak menganggapnya menyenangkan dan mengandaikan kebebasan; bagi guru, itu adalah cara yang "menyenangkan" di mana ia memberikan pembelajaran dan pengembangan kepada anak-anak. Namun peneliti lain, di antaranya Cruz dan Santos (2016), menemukan bahwa permainan pedagogis dan permainan terbimbing lebih dihargai oleh guru PAUD, dibandingkan dengan permainan bebas, yang dihargai oleh anak-anak. Guru mulai dari perspektif sekolah sebagai tempat belajar huruf, angka dan bentuk perilaku yang tepat dari orang dewasa yang produktif dan berpendidikan. Meskipun, pada saat-saat tertentu, menegaskan pentingnya bermain dalam perkembangan anak, praktiknya mengungkapkan persepsinya tentang bermain bebas sebagai "berantakan". Di sisi lain, permainan pedagogis, yang dia hargai, tidak diakui sebagai permainan oleh anak-anak. Bagi mereka, ruang aktivitas bukanlah tempat untuk bermain, tapi area bermain dan istirahat adalah ruang dan waktu untuk bermain di sekolah, masing-masing. Kemudian, dapat disimpulkan bahwa, mulai dari ruang kegiatan sebagai prototipe pengaturan sekolah, baik anak-anak maupun guru membayangkan sekolah dipisahkan dari permainan bebas.

Dalam beberapa tahun terakhir penelitian anak usia dini telah difokuskan terutama pada pembelajaran dan perkembangan anak-anak, dengan perhatian kurang terfokus pada pengajaran 
(Ryan \& Goffin, 2008). Namun, dalam dua puluh tahun terakhir para peneliti telah mengalihkan pandangan ke guru dan dampak pada lingkungan belajar awal (Genishi, Ryan, Ochsner \& Yarnall, 2001). Para peneliti sekarang mengidentifikasi guru sebagai variabel kunci dalam pendidikan anak usia dini yang berkualitas, dan telah menemukan bahwa tanpa pengajaran yang efektif, anak-anak tidak memiliki akses ke pengalaman pendidikan yang mereka butuhkan untuk berhasil (Barnett, 2003; Leithwood, Louis, Anderson, \& Wahlstrom, 2004; Whitebook \& Ryan, 2011). Dari interaksi guru-siswa di kelas, hingga keyakinan pribadi mereka tentang teori dan kebijakan, pekerjaan guru telah diakui sebagai bagian penting dari apa yang membuat kelas sukses. Interaksi guru-siswa telah ditemukan memainkan peran utama dalam kualitas pendidikan, telah menjadi bagian penting untuk penelitian dan kebijakan yang melibatkan guru dan pengajaran (de Kruif, McWilliam, Ridley, \& Wakely, 2000; Whitebook \& Ryan, 2011).

Interaksi yang dilakukan guru dengan anak saat bermain dapat membentuk kualitas pengalaman bermain tersebut. Ada berbagai peran yang diselidiki dan direkomendasikan untuk dilakukan oleh guru ketika anak-anak bermain; ini berkisar dari pengamat luar dan fasilitator hingga pemain aktif (Hadley, 2002; Hirsh-Pasek, Golinkoff, Berk \& Singer, 2009; Jones \& Reynolds, 2011; Kontos, 1999; Korat, Bahar \& Snapir, 2003). Konsensusnya adalah bahwa dari luar permainan, atau dari dalam, guru perlu membuat pilihan yang cermat tentang cara mereka terlibat dengan anakanak, berdasarkan pemahaman mereka tentang tujuan permainan dan tujuan pengajaran mereka sendiri. Berpikir tentang mengapa seorang guru mengambil pendekatan khusus untuk (atau peran dalam permainan) menempatkan guru di garis depan tentang apa artinya memfasilitasi bermain di kelas anak usia dini dan menarik perhatian kita pada perspektif dan keyakinan guru sendiri tentang nilai bermain. "Pedagogi bermain" seorang guru adalah ekspresi praktis dari ide-ide pribadi dan profesional mereka tentang bermain di kelas anak usia dini (Ryan \& Northey-Berg, 2013, hlm. 4), termasuk penyediaan waktu, ruang, materi, dan derajat keterlibatan guru langsung dalam permainan anak-anak.

"Perangkat alat pedagogis" yang dibawa setiap guru ke kelas mereka tidak hanya mencakup keterampilan yang dipelajari dalam program pendidikan guru, tetapi juga pengalaman, ingatan, dan nilai pribadi (Ayers, 1989; Ryan \& Northey-Berg, 2013). Kenangan dan pengalaman pribadi ini dapat diingat dan diproses melalui refleksi berbasis pedagogis. Seorang "praktisi reflektif" (Schön, 1983), adalah orang yang memahami bahwa mengajar bukanlah jalan satu arah; melainkan hubungan dinamis antara guru, anak-anak, konteks dan sejarah. Ruang bagi guru untuk mengeksplorasi dan memeriksa hubungan dan pengalaman dengan bermain ini menyediakan platform untuk pengakuan masa lalu mereka dalam kaitannya dengan bagaimana mereka berpikir tentang, memungkinkan, dan terlibat dalam bermain sekarang sebagai seorang profesional. Ada berbagai perspektif di antara guru tentang peran bermain dalam pembelajaran di PAUD. Beberapa guru percaya bermain terpisah dari belajar dan kebanyakan bermanfaat bagi perkembangan sosial dan emosional anak dan dengan demikian seharusnya tidak diinterupsi oleh guru (Fesseha \& Pyle 2016; Pramling Samuelsson dan Johansson 2006). Penelitian lain menunjukkan bahwa guru percaya bermain menjadi penting dalam konteks baik untuk perkembangan anak maupun untuk belajar keterampilan akademik (Fesseha \& Pyle 2016). Dalam perspektif ini, bermain, sering diidentifikasi sebagai pembelajaran berbasis bermain, dipandang secara aktif melibatkan pembelajar sambil memberikan instruksi dalam keterampilan akademik penting (Hirsh-Pasek, Golinkoff, Berk \& Singer, 2009; Van Oers \& Duijkers 2013; Weisberg dkk.,2013). Penelitian menunjukkan bahwa keyakinan guru tentang peran bermain dalam pembelajaran anak-anak berdampak pada bagaimana mereka menerapkan bermain di kelas mereka (Fesseha \& Pyle 2016). Secara khusus, penelitian telah menemukan bahwa guru yang percaya bermain dan belajar sebagai konstruksi dikotomis, di mana bermain sangat bermanfaat untuk perkembangan sosial dan emosional anak-anak, lebih mungkin untuk menerapkan permainan bebas di kelas mereka dengan keterlibatan guru yang minimal 
(Pramling Samuelsson \& Johansson 2006; Pyle \& Bigelow 2015; Pyle \& Daniels 2016). Guru yang percaya bahwa bermain penting untuk mendukung pembelajaran akademik anak-anak, sebaliknya percaya bahwa keterlibatan guru selama bermain diperlukan dan lebih mungkin untuk menerapkan berbagai jenis permainan di kelas mereka, mulai dari konteks bermain yang lebih diarahkan pada anak hingga yang lebih diarahkan oleh guru di kelas untuk memenuhi keterampilan akademik yang ditargetkan (Pyle \& Daniels 2016), seperti membaca dan menulis.

Rengel (2014) melakukan wawancara dengan 30 guru prasekolah di Kroasia untuk mendapatkan wawasan tentang sikap guru prasekolah terhadap permainan anak-anak. Guru prasekolah berpikir bahwa anak-anak saat ini bermain lebih jarang, kurang imajinatif dan kurang beragam daripada ketika mereka masih anak-anak. Namun, ketika ditanya berapa banyak waktu yang mereka dedikasikan untuk bermain dalam jadwal mereka, sebagian besar guru mencatat bahwa itu tergantung pada rencana kegiatan pendidikan dan tampaknya memprioritaskan kegiatan yang direncanakan guru daripada bermain. Studi berkontribusi pada kesadaran yang lebih dalam tentang sikap pendidik anak usia dini dan praktik yang dilaporkan dalam kaitannya dengan permainan anak-anak. Studi-studi ini menunjukkan bahwa mungkin ada perbedaan antara keyakinan dan praktik aktual pada guru prasekolah dalam hal memfasilitasi interaksi sosial di antara anak-anak prasekolah mereka.

Penelitian lebih baru yang dilakukan dengan siswa dalam program pendidikan pengajaran anak usia dini menemukan bahwa kompetensi bermain (yaitu kompetensi dalam mendukung anakanak dalam bermain, menciptakan lingkungan belajar yang menantang untuk bermain, d11) dinilai relatif rendah oleh siswa (Lillvist, Sandberg, Sheridan, \& Williams, 2014). Temuan ini mungkin menyiratkan bahwa dari perspektif siswa, kurikulum guru prasekolah belum sepenuhnya mengembangkan kompetensi mereka dalam mendukung anak-anak. bermain (Lillvist, Sandberg, Sheridan, \& Williams, 2014). Sebuah tinjauan dari 18 program lisensi guru anak usia dini yang terakreditasi di Amerika Serikat menemukan bahwa tidak ada kursus yang berfokus pada permainan dan hanya satu kursus yang menyebutkan permainan dalam deskripsi kursusnya (Vu, Han \& Buell, 2012). Temuan ini menunjukkan bahwa guru anak usia dini mungkin tidak menerima pengetahuan dan keterampilan yang cukup untuk memfasilitasi permainan sosial dalam program pendidikan mereka.

\section{PEMBAHASAN}

Permainan anak-anak adalah cara untuk mempromosikan penalaran, komunikasi, toleransi, kontrol emosional dan kompromi (Nicolopoulou, Barbosa de Sa, Ilgaz, \& Brockmeyer, 2010; Vygotsky, 1967). Bermain lebih dari sekadar memberi anak pilihan untuk berinteraksi secara bebas tanpa menerapkan aktivitas terkait instruksi apa pun yang akan mendorong kreativitas (Nicolopoulou, Barbosa de Sa, Ilgaz, \& Brockmeyer, 2010; Vygotsky, 1967). Bermain, baik yang diprakarsai oleh guru atau pilihan bebas menjadi bermakna ketika menjadi bagian dari pengalaman belajar (Gilbert, Harte \& Patrick., 2011). Oleh karena itu, masalah khusus yang harus diatasi adalah pengembangan kurikulum berbasis bermain yang efektif untuk mendukung kesiapan sekolah anak prasekolah akan lebih sulit diterapkan jika faktor-faktor yang berkaitan dengan keyakinan orang tua dan guru tentang pentingnya kurikulum berbasis bermain tidak dipahami dengan lebih baik. (Gilbert, Harte \& Patrick, 2011; Hatcher, Nuner, \& Paulsel, 2012; Howard, 2010). Peterson, Forsyth, dan McIntyre (2015) menemukan bahwa pendidik anak usia dini mencatat salah satu perjuangan terbesar mereka adalah membuat administrator dan orang tua melihat nilai dalam permainan.

Anak-anak menganggap bermain sebagai pengalaman yang berbeda dari guru. Guru, ketika berbicara tentang apa arti pengalaman bermain bagi anak-anak, membahas karakteristik penting dari 
bermain, jauh melampaui perolehan pengetahuan dan pelatihan keterampilan psikomotor, menyatakan kehadiran bermain di kehidupan anak-anak sebagai luar biasa. Hal yang perlu diingat adalah bahwa guru merasakan dua karakteristik penting dari permainan yang dipelajari oleh para ahli teori: bermain itu adalah bentuk komunikasi (Piaget, 1962; Vygotsky, 1978) dan dalam diri anak ada kebutuhan untuk menciptakan kembali realitas di dalamnya bertindak dalam situasi imajiner, beroperasi dengan makna yang terputus dari objek (Vygotsky, 1978). Ada perbedaan yang signifikan pada anak-anak dan perspektif guru tentang makna yang dikaitkan dengan bermain di lingkungan sekolah: anak-anak menganggapnya menyenangkan karena mengandaikan kebebasan; untuk guru, itu adalah cara "menyenangkan" di mana dia memberi anak-anak pembelajaran dan pengembangan. Namun peneliti lain, di antaranya Cruz dan Santos (2016), menemukan bahwa permainan pedagogis dan bermain terbimbing lebih dihargai oleh guru PAUD, merugikan permainan bebas, yang dihargai oleh anak-anak.

$\mathrm{Hal}$ ini tentu menjadi tantangan bagi guru terutama di level PAUD karena mungkin timbul harapan baik dari sekolah maupun orangtua bahwa guru dapat mengintegrasikan bermain dalam pembelajaran yang terbukti memiliki dampak positif bagi perkembangan moral, sosio-emosional, bahasa disaat yang bersamaan ada tuntutan akademis yang juga harus dipenuhi. Pemahaman yang lebih baik dari metode bermain sambil belajar ini adalah pemahaman bahwa bermain yang memberikan dampak positif bagi perkembangan anak usia dini justru adalah bentuk bermain yang bebas. Dan untuk dapat memahami konsep bermain bebas ini, seorang guru perlu memiliki pengalaman dan juga pengetahuan yang memadai. Seorang guru yang dapat memahami dan menerapkan konsep "praktisi reflektif" (Schön, 1983) yang dapat diartikan sebagai pemahaman bahwa mengajar bukanlah jalan satu arah; melainkan hubungan dinamis antara guru, anak-anak, konteks dan sejarah. Ruang bagi guru untuk mengeksplorasi dan memeriksa hubungan dan pengalaman dengan bermain ini menyediakan platform untuk pengakuan masa lalu mereka dalam kaitannya dengan bagaimana mereka berpikir tentang, memungkinkan, dan terlibat dalam bermain sekarang sebagai seorang profesional.

Pemahaman akan pentingnya peran bermain dalam pembelajaran dan perkembangan anakanak usia dini, (Elkind, 2008; Hirsh-Pasek, Golinkoff, Berk \& Singer, 2009; Gopnik 2009; Miller \& Almon, 2009), di samping pengakuan bahwa guru adalah bagian kunci dalam pendidikan anak usia dini yang berkualitas (Barnett, 2003; Leithwood, Louis, Anderson, \& Wahlstrom, 2004; Whitebook \& Ryan,2011) menciptakan ruang untuk bekerja yang terlihat pada hubungan antara guru dan bermain. Konstruksi identitas guru secara historis dianggap tunggal dan statis, (Day, Kington, Stobard \& Sammons, 2006) sedangkan penelitian yang lebih baru tentang perkembangan identitas guru menunjukkan bahwa perkembangan identitas tersebut sebenarnya dinamis. Mempertimbangkan pembangunan identitas sebagai proses yang aktif dan berkelanjutan (Beauchamp \& Thomas, 2009) memungkinkan ruang untuk memeriksa pembangunan identitas pribadi dari empat peserta dalam kerangka berbagi permainan seumur hidup. Ketika "pedagogi bermain" dianggap sebagai penggabungan pengetahuan pribadi, (siapa saya) dan pengetahuan berbasis praktik, (apa yang saya lakukan) (Ryan \& Northey-Berg, 2013), ini mencakup banyak aspek berbeda dari pengalaman bermain sehari-hari di kelas anak usia dini. Pilihan guru seputar materi, waktu, dan format untuk bermain adalah keputusan kunci yang harus dibuat yang diinformasikan oleh "perangkat alat pedagogis" yang mencakup keterampilan yang dipelajari dalam program pendidikan guru, dan pengalaman pribadi, ingatan dan nilai-nilai (Ayers, 1989; Ryan \& NortheyBerg, 2013).

Selain pemahaman terhadap perangkat pedagogi, kemampua merefleksikan diri pada guru, yang diinformasikan oleh pengalaman hidup di dalam dan di sekitar bermain, membangun sejarah bermain dan proses pembangunan naratif dapat digunakan sebagai alat yang berguna dalam proses reflektif yang diarahkan pada perubahan. Dengan memeriksa pemahaman teoretis mereka tentang 
permainan dan apa yang mereka anggap sebagai keterampilan mereka sebagai praktisi permainan, para guru mengidentifikasi dan dengan bangga memiliki peran kunci dalam kehidupan bermain siswa mereka. Area introspeksi pedagogis ini menginformasikan persepsi individu tentang kemampuan mereka saat ini sebagai guru yang bermain, tetapi juga mendorong para peserta untuk memikirkan cara-cara di mana mereka dapat meningkatkan kualitas interaksi bermain mereka di dalam kelas. Guru dapat mengambil berbagai peran dalam permainan dramatis siswa mereka sebagai salah satu cara untuk meningkatkan kualitas interaksi bermain dalam kelas. Guru dapat memilih untuk memasuki permainan atau tidak tergantung pada konteks skenario permainan, tetapi yang paling penting adalah kualitas interaksi tersebut. Dalam memeriksa konseptualisasi pribadi tentang bermain dan praktik bermain saat ini melalui lensa identitas pemain mereka, guru dapat memiliki pemahaman yang lebih jelas tentang mengapa mereka melakukan apa yang mereka lakukan, dan melihat secara komprehensif pilihan pedagogis mereka seputar bermain. Dengan demikian sejarah bermain pada guru adalah bentuk pendalaman pengetahuan praktis dan mendasar yang dapat digunakan untuk pengembangan pribadi dan professional masing-masing individu.

\section{SIMPULAN}

Studi ini dibingkai dalam iklim akademik saat ini di mana bermain telah berkurang di ruang kelas anak usia dini (Falk, 2012; Hirsh-Pasek, Golinkoff, Berk \& Singer, 2009; Miller \& Almon, 2009). Bidang pendidikan anak usia dini masih tidak memiliki definisi bermain, gambaran yang jelas tentang bagaimana bermain itu digunakan di seluruh konteks dan bagaimana definisi bermain mempengaruhi proses belajar pada anak usia dini. Jurang antara teori bermain dan belajar dan juga implementasi bermain sambil belajar dalam pendidikan anak usia dini berpotensi menimbulkan ketegangan pada proses mengajar guru. Guru terutama pada PAUD dituntut untuk dapat mengintegrasikan bermain sambil belajar. Tujuannya jelas, agar anak-anak usia dini tidak tertekan saat belajar di sekolah dan tuntutan akademis dapat terpenuhi. Inti dari ketegangan ini terletak pada negosiasi mandat bagi guru untuk melaksanakan pendekatan pedagogis kurikulum yang muncul di ruang kelas, sementara juga bertanggung jawab untuk memastikan siswa mereka memenuhi standar akademik. Namun, kembali lagi, definisi bermain yang masih sangat luas, dapat diimplementasikan secara berbeda oleh masing-masing guru. Deskripsi sebelumnya menjelaskan bahwa guru adalah kunci dari keberhasilan metode pembelajaran di sekolah. Sehingga hal-hal yang membentuk cara pengajaran guru akan sangat berpengaruh pada metode pembelajaran yang diterapkan. Untuk beberapa guru yang melibatkan partisipasi dalam metode pembelajaran, ketegangan tersebut diatasi dengan memisahkan pengembangan keterampilan literasi inti dari bermain, sementara yang lain memeluk permainan sebagai platform untuk akademisi yang kaya belajar. Apa yang terlihat jelas adalah bahwa integrasi standar berbasis kurikulum dan pendekatan pedagogis yang muncul dari pembelajaran berbasis bermain menghadirkan tantangan; tetapi tidak semua guru dapat mengatasi tantangan ini, bahkan pada guru yang menerapkan partisipasi aktif dalam pembelajaran. Di ruang kelas di mana guru menyatakan keyakinan pada nilai bermain sebagai platform untuk belajar, terdapat komitmen dan integrasi terhadap permainan dan literasi dalam variasi konteks permainan yang lebih luas dan dengan frekuensi yang lebih banyak.

Mengingat bahwa bermain dan peran guru di dalamnya merupakan komponen kunci dari apa yang dianggap sebagai pendidikan anak usia dini yang berkualitas, pemahaman tentang bagaimana guru menafsirkan permainan menjadi perhatian khusus. Menurut Clandinin \& Connelly (2000), identitas guru dibentuk melalui narasi guru tentang diri mereka sendiri, yang (ketika identitas dianggap cair dan dinamis). Dalam berbagi pengalaman mereka dengan bermain di dalam dan di luar kelas, guru dapat mengekspos kekuatan mereka sebagai pemain dan sebagai praktisi yang bermain. Pengakuan dan kepemilikan kekuatan permainan ini, dapat membingkai ulang identitas, 
mendorong bentuk penilaian diri yang produktif. Ini bisa sangat berharga bagi guru yang mengalami kesulitan memasukkan permainan ke dalam kelas mereka. Namun, guru dalam kelompok bermain dan pengembangan menggambarkan kurangnya koneksi antara bermain dan pembelajaran keterampilan akademik, menunjukkan integrasi yang jauh lebih sedikit pembelajaran literasi dalam bermain. Di beberapa yang berbeda negara yang telah mengamanatkan pembelajaran berbasis bermain di kurikulum taman kanak-kanak, masih ada kekurangan konsensus tentang peran yang tepat dan manfaat bermain dalam pendidikan dini. Deskripsi sebelumnya menunjukkan pengaruh penting dari konsep, perspektif guru terhadap bermain dan juga pengalaman sebelumnya pada guru berperan dalam implementasi yang efektif dari pedagogi bermain. Dengan demikian, maka sudah lebih jelas bahwa untuk menjamin keberhasilan dari metode pembelajaran bermain sambil belajar yang banyak digaungkan terletak pada kemampuan guru untuk mengolah pemahaman dan pengalaman mereka dalam bermain untuk dterjemahkan ke dalam kurikulum atau milestones yang ingin dicapai di ruang kelas.

\section{DAFTAR PUSTAKA}

Ayers, W. (1989). The good preschool teacher: Six teachers reflect on their lives. New York: Teachers College Press.

Barnett, W. S. (2003). Better Teachers, Better Preschools: Student Achievement Linked to Teacher Qualifications. NIEER Preschool Policy Matters, Issue 2.

Barnett, W. S., \& Camilli, G. (2002). Compensatory preschool education, cognitive development, and "race" In J. M. Fish (Ed.), Race and intelligence: Separating science from myth (pp. 369-406). Mahwah, NJ: Lawrence Erlbaum Associates Publishers.

Beauchamp, C., \& Thomas, L. (2009). Understanding teacher identity: an overview of issues in the literature and implications for teacher education. Cambridge Journa of Education (39)2, 175-189.

Bodrova, E., \& Germeroth, C. (2013). Play and self-regulation lessons from Vygotsky.American Journal of Play, 6(1), 111.

Bowman, B., Donovan, M.S., \& Burns, M.S. (2000). Eager to learn. Washington D.C.: National Academy Press.

Brown, C. P., \& Lan, Y. (2015). A qualitative metasynthesis comparing U.S. teachers' conceptions of school readiness prior to and after the implementation of NCLB.Teaching and Teacher Education, 451-13.

Chervenak, R. (2011). Play in kindergarten: Perspectives of a full-and half-day kindergarten teacher (Document No. bgsu1307916817). Diunduh dari https://etd.ohiolink.edu/

Clandinin, D. J., \& Connelly, F. M. (2000). Narrative inquiry: Experience and story in qualitative research. San Francisco: Wiley.

Cutter-Mackenzie, A., \& Edwards, S. (2013). Toward a model for early childhood environmental education: Foregrounding, developing, and connecting knowledge through play-based learning. The Journal of Environmental Education, 44(3), 195-213

Cruz, S. H. V., \& Santos, C. O. (2016). Perspectivas de crianças sobre o cotidiano da pré-escola: O recreio em foco [Children's perspectives on pre-school daily life: Recreation in focus]. Textura: Revista de Educação e Letras, 18(36), 171-191

Day, C., Kington, A., Stobart, G., \& Sammons, P. (2006). The personal and professional selves of teachers: Stable and unstable identities. British Educational Research Journal, 32(4), 601-616.

DellaMattera, J. (2010). No preschooler left behind: Preschool policies in the NCLB world. Journal of Educational Research \& Policy Studies, 10(1), 35-49. 
de Kruif, R. E., McWilliam, R. A., Ridley, S. M., \& Wakely, M. B. (2000). Classification of teachers' interaction behaviors in early childhood classrooms. Early Childhood Research Quarterly, 15(2), 247-268.

Drew, W. F., Christie, J., Johnson, J. E., Meckley, A. M., Nell, M. L., \& Chalufour, I. (2008). A value-added strategy for meeting early learning standards. YC Young Children, 63(4), 38-44.

Elkind, D. (2008). Some misunderstandings of school readiness. Exchange. March/April 49-52.

Falk, B. (2012). Defending childhood: Keeping the promise of early education. New York: Teachers College Press.

Faulkner, J. (2011). The importance of being innocent: Why we worry about children. New York, NY: Cambridge University Press.

Fesseha, E., \& Pyle, A. (2016). Conceptualizing play-based learning from kindergarten teachers' perspectives. International Journal of Early Years Education, 0(00), 361-377.

Genishi, C., Ryan, S., Ochsner, M., \& Yarnall, M. (2001). Teaching in early childhood education: Understanding practices through research and theory. In V. Richardson (Ed.), Handbook of research on teaching 4th ed. (1175-1210). Washington DC: American Educational Research Association.

Gilbert, J. L., Harte, H. A., \& Patrick, C. (2011). Purposeful play leads to school readiness. Dimensions of Early Childhood, 39(1), 29-37.

Gopnik, A. (2009). The philosophical baby: What children's minds tell us about truth, love, and the meaning of life. New York: Farrar, Straus \& Giroux.

Gray, P. (2011). The decline of play and the rise of psychopathology in children and adolescents. American Journal of Play, 3(4), 443-463.

Gray, P. (2014). School Overload. Education Canada, 54(2), 9.

Hadley, E. (2002). Playful disruptions. Early Years, 22(1), 9-17

Hatcher, B., Nuner, J., \& Paulsel, J. (2012). Kindergarten readiness and preschools:Teachers' and parents' beliefs within and across programs. Early Childhood Research \& Practice, 14(2).

Hirsh-Pasek, K. Golinkoff, R.M., Berk, L.E., \& Singer. D.G. (2009). A mandate for playful learning in preschool: Presenting the evidence. New York: Oxford University Press.

Howard, J. (2010). Early year' s practitioners' perceptions of play: An exploration of theoretical understanding, planning and involvement, confidence and barriers to practice. Educational \& Child Psychology, 27(4), 91-102.

Jones, E., \& Reynolds, G. (2011). The play's the thing: Teachers' roles in children's Play (2nd Ed.) New York: Teachers College Press.

Katz, L. G. (2015). Lively minds: Distinctions between academic versus intellectual goals for Young Children. Defending the Early Years Publications.

Kemple, K. M. (1996). Teachers' beliefs and reported practices concerning sociodramatic play. Journal of Early Childhood Teacher Education, 17(2), 19-31

Kohn, Alfie. (1999). Early childhood education: The case against direct instruction of academic skills. Boston Houghton Mifflin. Diunduh dari http://www.alfiekohn.org/article/earlychildhood-education/

Kontos, S. (1999). Preschool teachers' talk, roles, and activity settings during free play. Early Childhood Research Quarterly, 14, 363-382.

Korat, O., Bahar, E., \& Snapir, M. (2003). Socio-dramatic play as opportunity for literacy development: The teacher's role. The Reading Teacher, 56(4), 386-393.

Leithwood, K., Seashore Louis, K., Anderson, S., \& Wahlstrom, K. (2004). Executive Summary: Review of Research: How Leadership Influences Student Learning. 
Lillvist, A., Sandberg, A., Sheridan, S., \& Williams, P. (2014). Preschool teacher competence viewed from the perspective of students in early childhood teacher education. Journal of Education for Teaching, 40(1), 3-19.

Martins, C. A, \& Cruz, S. H. V. (2020). The children's and the teacher's participation in the constitution of playing in school. Paidéia (Ribeirão Preto), 30, e3016

Miller, E., and Almon, J. (2009) Crisis in the kindergarten: Why children need to play in school. College Park, MD: Alliance for Childhood.

Myck-Wayne, J. (2010). In defense of play: Beginning the dialogue about the power of play. Young Exceptional Children, 13(4), 14-23.

National Association for the Education of Young Children. (2003). Early Childhood Curriculum, Assessment, and Program Evaluation: Building an Effective, Accountable System in Programs for Children Birth through Age 8. Position Statement. Diunduh dari https://www.naeyc.org/files/naeyc/file/positions/pscape.pdf.

National Association for the Education of Young Children (NAEYC). (2009). Developmentally appropriate practice in early childhood programs serving children from birth through age 8. Diunduh dari https:// www.naeyc.org/positionstatements/dap

National Association of School Psychologists. (2005). Position Statement on Early Childhood Assessment, diunduh dari http://www.nasponline.org/about_nasp/pospaper_eca.aspx.

Nicolopoulou A, Barbosa De Sa A, Ilgaz H, Brockmeyer C.(2010). Using the transformative power of play to educate hearts and minds: From Vygotsky to Vivian Paley and beyond. Mind, Culture, And Activity, 17(1):42-58

Peterson, S. S., Forsyth, D., \& McIntyre, L. J. (2015). Balancing play-based learning with curricular mandates: Considering the views of Northern Canadian teachers and early childhood educators. Canadian Children, 40(3), 40-47

Piaget, J. (1962) Play, dreams and imitation in childhood. New York: Norton

Pramling-Samuelsson, I., \& Fleer, M. (2010). Commonalities and distinctions across countries. In

Pramling-Samuelsson, \& M. Fleer (Eds.), Play and learning in early childhood settings (pp.173-190).

New York, NY: Springer.

Pyle, A., \& Bigelow, A. (2015). Play in kindergarten: An interview and observational study in three Canadian classrooms. Early Childhood Education Journal, 43(5), 385-393.

Pyle, A., \& Danniels, E. (2016). A continuum of play-based learning: The role of the teacher in playbased pedagogy and the fear of hijacking play. Early Education and Development, O(00), 1-16.

Rengel, K. (2014). Preschool teachers' attitudes towards play. Croatian Journal of Education, 16(1), $113-125$.

Ryan, S. \& Goffin, S.G. (2008). Missing in Action: Teaching in Early Care and Education, Early Education \& Development, 19(3), 385-395

Ryan, S., \& Northey-Berg, K. (2013). Professional preparation for a pedagogy of play. In E. Brooker, S. Edwards, \& M. Blaise, (Eds.) The SAGE handbook of play and learning in early childhood (204-215) Thousand Oaks, CA: Sage.

Samuelsson, I. P., \& Carlsson, M. A. (2008). The playing learning child: Towards a pedagogy of early childhood. Scandinavian Journal of Educational Research, 52(6), 623-641.

Sandberg, A., \& Ärlemalm-Hagsér, E. (2011). The Swedish national curriculum: Play and learning with fundamental values in focus. Australasian Journal of Early Childhood,36(1), 44-50.

Schön, D.A. (1983) The reflective practitioner: How professionals think in action. New York: Basic Books

Singer, E. (2015). Play and playfulness in early childhood education and care. Psychology in Russia, $8(2), 27-35$.

Shonkoff, J.P., \& Phillips, D. (2000). From neurons to neighborhoods: The science of early childhood development. Washington D.C.: National Academy Press. 
Van Oers, B., \& Duijkers, D. (2013). Teaching in a play-based curriculum: Theory, practice and evidence of developmental education for young children. Journal of Curriculum Studies, 45, 511-534.

Vu, J. A., Han, M., \& Buell, M. J. (2012). Preserving play in early childhood classrooms: Suggestions for early childhood teacher education and policy. In L. E. Cohen \& S.WaiteStupiansky (Eds.), Play: A polyphony of research, theories, and issues. Play \& culture studies (207221). New York, NY: University Press of America

Vygotsky, L. S. (1967). Play and its role in the mental development of the child. Soviet psychology, 5(3), 6-18.

Vygotsky, L. S. (1978). Mind in society: The development of higher mental processes. Cambridge, MA: Harvard University Press

Wasik, B., \& Jacobi-Vessels, J. (2017). Word play: Scaffolding language development through childdirected play. Early Childhood Education Journal, 45(6), 769-776.

Weisberg, D. S., Hirsh-Pasek, K., \& Golinkoff, R. M. (2013). Guided play: Where curricular goals meet a playful pedagogy. Mind, Brain, and Education, 7, 104-112

Whitebook, M., \& Ryan, S. (2011). Degrees in Context: Asking the Right Questions about Preparing Skilled and Effective Teachers of Young Children. Preschool Policy Brief. Issue 22. National Institute for Early Education Research. 